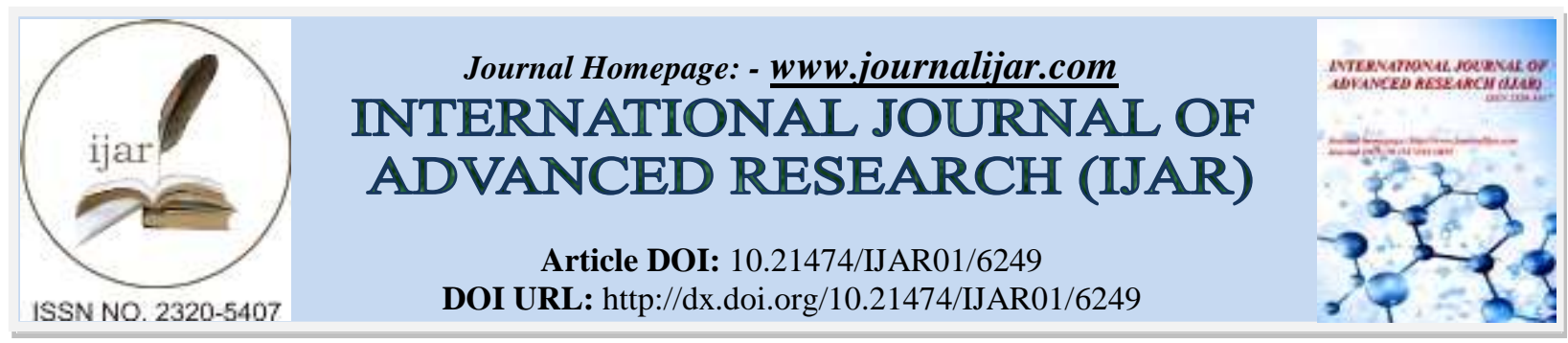

RESEARCH ARTICLE

\title{
ASSESMENT OF MINERAL, PROXIMATE AND PHYTOCHEMICAL COMPOSITION OF LEAF, STEM AND ROOT OF Maesobotrya barteri (BAILL) FROM SECONDARY FOREST IN AKWA IBOM STATE.
}

Mbosowo M. Etukudo ${ }^{1}$ and Samuel E. Osim ${ }^{2}$.

1. Department of Biology, Federal University Otuoke, PMB 126, Bayelsa State, Nigeria

2. Department of Biological Sciences, Cross River University of Technology, Calabar, Cross River State, Nigeria.

\section{Manuscript Info}

\section{Manuscript History}

Received: 08 November 2017

Final Accepted: 10 December 2017

Published: January 2018

Key words:-

Mineral, proximate, phytochemical,

Maesobotrya barteri, Akwa Ibom State.

\section{Abstract}

Introduction: This study was conducted to assess the mineral element, proximate, and phytochemical contents of the leaf, stem and root of Maesobotrya barteri (Baill) grown in a secondary forest habitat of Akwa Ibom State.

Methods: The dried and powdered leaf, stem and root of $M$. barteri were subjected to various sample preparation stages using standard laboratory procedures for determination of phytochemicals, mineral elements, and proximate composition in the test plant parts.

Results: The results showed that there were marked differences $(\mathrm{P}<0.05)$ in the phytochemical, mineral element contents and proximate value of the leaves, stems and roots of $M$. barteri. Tannin was the highest phytochemical compound in the leaf, stem and root of the test plant. Alkaloids, flavonoids, and saponins were present in moderate amount. Of all the macro elements examined, calcium and potassium had the highest values in M. barteri. Magnesium, sodium, and nitrogen contents were found in moderate proportions in leaf, stem and root of $M$. barteri. Similarly, the contents of micro elements showed the highest values of iron and zinc. Carbohydrate found in the leaf, stem and root of the test plant, respectively, had the highest proximate content, although, the dry matter content was also prominent in the analysis.

Conclusion: This study suggests that the phytochemical values and nutritional components of leaf, stem and root of $M$. barteri could be utilized as a good source of nutrient supplement, as well as source of useful pharmaceutical products.

Copy Right, IJAR, 2018,. All rights reserved.

\section{Introduction:-}

Many indigenous plants are utilized as spices, food, ornamentals or medicinal plants [1,2]. Proximate and elemental analyses of medicinal plants, edible fruits and vegetables play a crucial role in evaluating their nutritional significance [3, 4]. Assessment of nutritional components of plants can reveal the potential benefits of these plant species, since some medicinal plant species are also consumed as food along with their medicinal importance [3, 5 \}.These nutrients could be of crucial importance as certain inorganic mineral elements and proximate components are known to play pivotal roles in the maintenance of the body [6, 7]. Medicinal and aromatic plants contain 
bioactive compounds which inhibit the activities of bacteria and other microorganisms [8].These biological active chemical substances include among others, saponins, tannins, flavonoids, alkaloids, anthocyanin and steroids [8].

The presence of these bioactive compounds confer on these plants the medicinal properties from which important drugs could be prepared $[9,5]$. Phytochemicals are secondary metabolites formed during the normal metabolic processes in plants [10]. There are many groups of phytochemicals that help the body in various ways through their mechanisms of action, which may be complementary and overlapping in nature, such as stimulation of metabolism, antibacterial and antiviral effects, and antioxidant effects [10, 11].

Although, plant material contains a variety of nutrients, there is less awareness that many plant parts also contain small proportion of potentially harmful substances, which are regarded as toxins or antinutrients [12, 13]. Since phytochemicals, nutrients and antinutrients are found in some levels in almost all edible plant materials, it is necessary to test for their presence in Maesobotrya barteri. Similarly, partial and temporal variation in distribution of nutrients and phytochemicals in plant parts require appropriate analysis to ascertain their utilization in nutrition and production of drugs.

Maesobotrya barteri Baill is a notable species belonging to the Euphorbiaceae family [14]. Phytochemicals such as tannins, saponins, cardiac glycosides, deoxy sugar and terpenes have been indicated as components of this species [15]. Its medicinal importance include, utilization for treatment of diarrhea, stomach ache, malaria and pain [16, $17]$.

Series of studies have been carried out on phytochemical, mineral and proximate compositions of various plants, however, this present study was conducted to evaluate the distribution of phytochemical, elemental and proximate contents in leaf, stem and root of M. barteri from the secondary forest of Akwa Ibom State, Nigeria.

\section{Materials and Methods:- \\ Collection of sample:}

Plant samples (leaf, stem and root) of $M$. barteri were collected from the test plant in a secondary forest habitat in Abak, Akwa Ibom State, Nigeria. Abak is located at coordinates of $40^{\circ} 33 \mathrm{~N}$ and $70^{\circ} 33^{`} \mathrm{E}$. Akwa Ibom State has an Altitude of 106m AMSL (Above Mean Sea Level) and is located within the humid tropical rainforest Zone of South eastern Nigeria. The mean annual rainfall is about $2000 \mathrm{~mm}$, while the mean annual minimum and maximum temperature are $23^{0} \mathrm{C}$ and $31.7^{0} \mathrm{C}$, respectively $[18,19]$.

\section{Determination of Phytochemicals:-}

The dried and powdered plant material (leaf, stem and root) of M. bateri were subjected to various sample preparation stages using standard laboratory procedures for determination of phytochemicals (alkaloids, tannins, flavonoids, saponins, glycoside, phytate, oxalate and cyanide). Standard methods were used to determine the phytochemical contents in the test plant; alkaloid [20], tannin [21], flavonoids [22], saponnin [23], cyanide [24, 25], phytate [26], and oxalate [27].

\section{Determination of Mineral Elements:-}

Plant materials were rinsed with distilled water and dried. Pestle and mortar was used to grind the dried plant material of each sample into powder form. Sieving of the powdered sample to obtain a fine powdered form was carried out using a $0.002 \mathrm{~mm}$ wire mesh. Each sample of the fine powdered plant material was kept in small bottles for analysis. The following mineral elements (magnesium, calcium, sodium, nitrogen, phosphorus, potassium, zinc, lead, iron, manganese, and copper) were determined using standard methods [28, 29]. Standard MicroKjedahl method was used to estimate the total nitrogen concentration in the plant dry matter. Phosphorus was determined spectrophotometrically by ammonium-vanadate-molybdate method, potassium by using a frame photometer and other elements by atomic absorption spectrophotometer.

\section{Determination of Proximate composition:-}

The proximate compositions (moisture, lipid, crude protein, crude fibre, ash, dry matter, nitrogen free extract) of plant material were determined using standard method of [28]. 


\section{Statistical Analysis:-}

Standard errors of the mean values were calculated for the separate readings and data were subjected to analysis of variance (ANOVA) to compare the means at 0.05 confident interval [30].

\section{Results:-}

The leaf of Maesobotrya barteri recorded the highest contents of alkaloid, tannin, phytate and cyanide, while the root had the highest contents of flavonoid and glycosides. Similarity, the stem of M. barteri had the highest contents of saponin and oxalate (Table 1). The leaf of $M$. Barteri had the highest contents of magnesium, potassium, iron, manganese, copper, phosphorous and nitrogen. The highest contents of calcium, sodium and zinc were recorded in the root of M. barteri while the stem and leaf had the same proportion of lead (Table 2). The leaf of M. barteri had the highest contents of protein and lipid and lowest contents of ash, fibre and nitrogen free extract. The root of the test plant had the highest contents of moisture, ash, and nitrogen free extract, and lowest contents of protein, and dry matter while the stem had the highest contents of fibre and dry matter and lowest contents of moisture and lipid (Table 3).

Table 1:- QUANTITATIVE COMPOSITION OF Maesobotrya barteri

\begin{tabular}{|c|c|c|c|c|c|c|c|c|}
\hline Parameters (\%) & ) ALK & TAN & SAP & FLAV & GLY & PHY & OXAL & $\mathbf{C N}$ \\
\hline $\begin{array}{l}\text { Plant Parts } \\
\text { Leaf } \\
0.007 \pm 0.02\end{array}$ & $2.52 \pm 0.21$ & $12.56 \pm 0.27$ & $0.59 \pm 0.02$ & $0.36 \pm 0.02$ & $2.87 \pm 0.44$ & $0.062 \pm 0.03$ & $0.22 \pm 0.05$ & \\
\hline $0.003 \pm 0$ & $\begin{array}{l}1.26 \pm 0.12 \\
0.01\end{array}$ & $6.02 \pm 0.40$ & $0.73 \pm 0.04$ & $0.95 \pm 0.04$ & $3.92 \pm 0.50$ & $0.025 \pm 0.01$ & $0.09 \pm 0.02$ & \\
\hline $0.005 \pm$ & $\begin{aligned} & 0.49 \pm 0.03 \\
= & 0.02\end{aligned}$ & $8.21 \pm 0.22$ & $1.35 \pm 0.32$ & $0.75 \pm 0.02$ & $1.13 \pm 0.14$ & $0.019 \pm 0.02$ & $0.24 \pm 0.04$ & \\
\hline
\end{tabular}

Mean \pm standard Error from 3 replicates.-

Table 2:- Mineral Elements Composition Of Maesobotrya Barteri

\begin{tabular}{|c|c|c|c|c|c|c|c|c|c|}
\hline $\begin{array}{l}\text { Mineral } \\
\text { Elements } \\
(\mathrm{Mg} / 100 \mathrm{~g})\end{array}$ & $\begin{array}{l}\mathrm{Ca} \\
\mathrm{PO} 4\end{array}$ & $\stackrel{\mathrm{Mg}}{\mathrm{N} 2}$ & $\mathrm{Na}$ & $\mathrm{K}$ & $\mathrm{Fe}$ & $\mathrm{Mn}$ & $\mathrm{Zn}$ & $\mathrm{Pb}$ & $\mathrm{Cu}$ \\
\hline \multicolumn{10}{|c|}{ Plant Parts } \\
\hline $\begin{array}{l}\text { Leaf } \\
0.39 \pm 0.10\end{array}$ & $\begin{array}{l}6.77 \pm 0.21 \\
4.21 \pm 0.13\end{array}$ & $4.69 \pm 0.54$ & $5.47 \pm 0.61$ & $7.29 \pm 0.14$ & $0.39 \pm 0.12$ & $0.05 \pm 0.01$ & $0.35 \pm 0.04$ & $0.001 \pm 0.00$ & $0.035 \pm 0$ \\
\hline $\begin{array}{l}\text { Root } \\
0.37 \pm 0.04\end{array}$ & $\begin{array}{c}8.43 \pm 0.36 \\
3.11 \pm 0.02\end{array}$ & $3.79 \pm 0.10$ & $6.51 \pm 0.36$ & $6.74 \pm 0.20$ & $0.27 \pm 0.61$ & $0.04 \pm 0.01$ & $0.43 \pm 0.10$ & $0.000 \pm 0.00$ & $0.019 \pm 0$ \\
\hline $\begin{array}{l}\text { Stem } \\
0.31 \pm 0.03\end{array}$ & $\begin{array}{l}4.39 \pm 0.20 \\
2.85 \pm 0.26\end{array}$ & $3.31 \pm 0.33$ & $4.26 \pm 0.45$ & $5.66 \pm 0.90$ & $0.19 \pm 0.45$ & $0.03 \pm 0.01$ & $0.37 \pm 0.03$ & $0.001 \pm 0.00$ & $0.021 \pm$ \\
\hline
\end{tabular}

Mean \pm standard Error from 3 replicates.

Table 3:- Proximate Composition Of Maesobotrya Barteri

\begin{tabular}{|lcclcccc|}
\hline $\begin{array}{l}\text { Proximate } \\
\text { Composition (\%) } \\
\text { C }\end{array}$ & Moisture & Ash & Protein & Lipid & Fibre & DM & NFE \\
\hline Plant Parts & & & & & & & \\
\hline $\begin{array}{l}\text { Leaf } \\
86.31 \pm 0.33\end{array}$ & $6.77 \pm 0.20$ & $2.43 \pm 0.43$ & $7.29 \pm 0.21$ & $1.47 \pm 0.02$ & $2.55 \pm 0.70$ & $93.25 \pm 0.61$ & \\
$\begin{array}{l}\text { Root } \\
90.73 \pm 0.62\end{array}$ & $7.55 \pm 0.50$ & $3.53 \pm 0.10$ & $2.55 \pm 0.37$ & $0.43 \pm 0.05$ & $2.81 \pm 0.26$ & $92.47 \pm 0.44$ & \\
$\begin{array}{l}\text { Stem } \\
90.49 \pm 0.52\end{array}$ & $\mathbf{5 . 8 9 \pm 0 . 7 2}$ & $2.85 \pm 0.40$ & $3.31 \pm 0.49$ & $0.39 \pm 0.06$ & $3.01 \pm 0.88$ & $94.13 \pm 0.50$ \\
\hline
\end{tabular}

Mean \pm standard Error from 3 replicates. 


\section{Discussion:-}

In this study, Maesobotrya barteri contained phytochemicals such as alkaloids, tannins, flavonoids, saponins, glycosides, phytate, oxalate and cyanide. In addition, the leaf had the highest content of this phytochemicals comparable with the root and stem. This result agrees with the work of [31, 32] that M. barteri contains high proportion of phytochemicals in the aerial parts of the plants. However in this study, tannin was the highest phytochemical from leaf, which contradict the reports of [32] that flavonoid was the most abundance phytochemical in the leaf extract of the species. The presence of these phytochemicals is a clear indication of its pharmacological relevance $[33,34,35]$. The presence of these bioactive compounds in the leaf, root and stem of this species corroborates the various medicinal uses both in synthetic and traditional practices [36]. Similarly, the low content of antinutrients such as phytate, oxalate and cyanide in the stem of this species as recorded in this study indicate that $M$. barteri could be utilized as chewing stick as reported by $[37,8]$.

In this study, the leaf, stem and root of $M$. barteri showed the presence of mineral elements such as $\mathrm{Ca}, \mathrm{Mg}, \mathrm{Na}, \mathrm{K}$, $\mathrm{Fe}, \mathrm{Mn}, \mathrm{Zn}, \mathrm{Pb}, \mathrm{Cu}, \mathrm{P}$ and $\mathrm{N}_{2}$. This implies that this species could be useful as supplements in human and animal nutrition. Mineral elements are needed in small proportions for the proper functioning of the human system, healthy growth and development $[38,39]$. In general, quantitative and qualitative determination of mineral elements present in plant parts is important in ascertaining the specific part of nutritional significance as well as an indication for the concentration and type of minerals to be stipulated on the label of food $[40,41]$.

The proximate composition of the leaf, stem and root of $M$. barteri showed the presence of carbohydrate, protein, lipid and other proximate components. Carbohydrates found in the three parts of this plant were the highest proximate content. Carbohydrates hydrolysis in the body yield glucose, which can be utilized immediately or stored as glycogen in the muscles and liver for future use [40]. Proteins help in cell division, growth, body building and are immune-boosters as well as replace worn out tissues [42, 43]. Lipids are instrumental in regulation of blood pressure of cellular parts in the body and important in energy production (Anoliefo, 2006). Moisture is regarded as a universal solvent that dissolves other substances, carries nutrients and other materials round the body, thus creating a medium for effective cellular functions [40,3].The parts of fruits, grains and vegetables which remains undigested, hence cannot be absorbed by the human system is known as fibre. It plays a crucial role in regulating the level of palm cholesterol as well as prevents colon cancer and cardiovascular diseases [13, 40, 43].

\section{Conclusion:-}

This study on distribution of phytochemicals, minerals and proximate contents of $M$. barteri would give new insight into potential use of their plant parts in pharmaceutical purposes, as well as in identifying new sources of nutritionally important compounds.

\section{Conflict of interest:-}

There was no conflict of interest between the two authors.

\section{Acknowledgements:-}

We wish to appreciate the contributions from Mr. Sunday Okpata, Department of Biology, and Mr Awolabi Akeem, Department of Biochemistry, Faculty of Science, Federal University Otuoke, Bayelsa State, Nigeria.

\section{References:-}

1. Chandran, P.R. Analysis of proximate, phytochemical, elemental compositions and antioxidant property of leaf of Alternanthera brasiliana (L.) Kuntze. MOJ. Food Proc. Tech, 2017, 4(3): 00090. DOI: 10.15406/mojfpt.2017.04.00090

2. Etukudo, M. M., Hamilton-Amachree, A., and Roberts, E. M. I. Eco-physiological studies of elemental and proximate contents of Gnetum africanum Welw and Telfairia occidentalis Hook seeds from two Ecological Zones of Akwa Ibom State. Europ. Intern. Journ. Sci. Tech. 2015 , 4(6):47-53.

3. Pandey, M., Abidi, A.B., Singh, S. and Singh, R.P. Nutritional evaluation of leafy vegetable Paratha. Journ. Hum. Ecology, 2006, 19 (2): 155-156.

4. Osim, S. E., Odoemena, C. S., Etukudo, M.M., Okonwu, K., and Eremrena, P. Evaluation of proximate composition of fruits of Lycopersicon esculentum (Roma VF) under stress and Staking. Glob. Journ. Pure App. Sci., 2010, 16(3), 277-279. 
5. Atangwho, I.J., Ebong, P.E., Eyong, E.U., William, I.O., Eteng, M.U., and Egbung, G.E. Comparative chemical composition of leaves some antidiabetic medicinal plants: Azadirachta indica, Vernonia amygdalina and Gongronema latifolium. Afri. Journ. Biotech., 2009, 8(18): 46854689

6. Ebun, O.P.O. and Alade, A.S. Nutritional potential of Berlandier Nettle Spurge (Jatropha cathatica) Seed. Pakistan Journ. Nutri., 2007, 6(4): 345-348.

7. Nelson, D.L., and Cox, M.M. Lehningers Principles of Biochemistry (4th ed.). New York, New York: W. H. Freeman and Company, 2005.

8. 8. Okwu, D.E. and Ekeke, O. Phytochemical screening and mineral composition of chewing sticks in South Eastern Nigeria. Glob. Journ. Pure App. Sci., 2003, 9:235- 238.

9. Okeke, C.U. and Nwachukwu, A.C. Phytochemical and Proximate Analyses of Euphorbia heterophylla Linn. (Euphorbiaceae). Nig. Journ. Bot., 2009, 22(1):215-222.

10. Izevbigie, E.B., Bryant, J.L. and Walker, A. A novel natural inhibitor ofextracellular signal-regulated kinases and human breast cancer cell growth. Experim. Bio. Med. (Maywood). 2004, 229(2):163-169

11. Urquiaga, I. and Leighton, F. Plant polyphenol antioxidants and oxidative Stress. Bio. Research, 2000, $33: 159-165$

12. Etukudo, M. M., Udo, Joseph I., and Ihimikaiye, Samuel . Evaluation of eco-physiological indices of Colocasia esculenta Schott along Elebere-Emayal-Otuoke road in Bayelsa State, Nigeria. Green. Journ. Bio. Sci., 2016, 6(5):084-088.

13. Gupta, N.K. and Gupta, S. Plant Physiology New Delhi. Oxford IBA Publishing Co. Pvt Ltd, 2005.

14. 14. Ogbuagu, M. N, and Agu, B. Fruit nutritive composition of Maesobotrya barteri, an underexploited tropical African tree. Fruits, 2008, 63 (6):357-61.

15. 15. Akan NE. Phytochemical analysis and in vitro antimicrobial studies of ethanolic leaf extract of Maesobotrya barteri. An unpublished B. Sc Thesis Department of Chemistry, University of Uyo, Uyo Nigeria; 2014.

16. Dalziel, J.M. The useful plants of West Tropical Africa. London UK: The Crown Agents for the Colonies. 1994, 612.

17. 17. Uduak A Essiett, Kola K Ajibesin. Antimicrobial activities of some Euphorbiaceae plants in the traditional medicine of Akwa Ibom State of Nigeria. Ethnobot. Leaflet, 2010,14:654 -64.

18. 18. nyang S . Statistical year book of Akwa Ibom State of Nigeria. 2013 Edn. Directorate of Statistics, Minitry of Economic Development Uyo, 2013.

19. 19. Wokocha, R.C.and Nneke, N.. Cassava Anthracnose disease and varietal screening for resistance in Akwa ibom State of Nigeria. Journ. Agric. Sci. Tech., 2011, B 1: 889-895.

20. 20. Harbone, Z.B. Phytochemical methods: A guide to modern techniques of plant Analysis, Chapman and Hall, London, 1973, pp. 113 - 185.

21. 21. Pearson, D. Chemical analysis of foods. (7th Ed), Henry Edward company, Churchchill, Livingstone, London, 1976, pp. 218- 336.

22. 22. Bohn, B.A. and Kocipai-Abyazan, R. Flavonoids and condensed tannins from the leaves of Hawaiian Vaccinium vaticulatum and $\quad$ V. $\quad$ calycinum. Pacific Science, 1994, 48:458-63.

23. 23. Obadoni, B.O. and Ochuko, P.O. Phytochemical studies and comparative efficiency of the extracts of some homoeostatic plants in Edo and Delta States of Nigeria. Glob. Journ. Pure and App. Sci., 2001, 8: 20308 .

24. Ikediobi C.O., Onyia G.O.C., and Eluwah E.C., A rapid and inexpensive enzymatic assay for total cyanide in cassava and cassava products. Agric. Biol. Chem. 1980, 44 (12), 2803-09.

25. Olugboji, O.O., Biochemical studies on the cyanide content of malted sorghum (Sorghum bicolor L. Moench) and sorghum products and the fate of sorghum dhurrin in the rat. M. Sc Thesis, Ahmadu Bello University, Zaria, Nigeria, 1987.

26. Oberlease, D. (1962). Phytates. F. Strong (Ed.), Toxicants Occurring Naturally in Foods, National Academy of Sciences, Washington D.C, 1962, pp. 363-71.

27. Oke, O.L Chemical studies on some Nigerian Vegetables. Trop. Sci. Trop. Sci., 1966, 8(3): 128-132.

28. A.O.A.C., Association of Official Analytical Chemist. Methods of analysis (16h Edition), Washington DC., U.S.A.1999.

29. Hack, B., Analytical method of determination of mineral nutrients. In: Dolphin and John, S (eds.). Text on analytical in practice, Incorp. Press Ltd. New York. 2000.

30. Obi, 1. U. Statistical Methods of Detecting Differences Between Treatment Means and Research Methodology Issues in Laboratory and Field Experiments. Nigeria, AP Express publishers limited, 2002. 
31. 31. Ogwuche, C.E, Amupitan, J.O, Ndukwe, I.G, Ayo, R.G. Isolation and biological activity of the Triterpene B- Amyrin from the aerial plant parts of Maesobotrya barteri. Med. Chem.. 2014, 4(11):729-733.

32. Dikioye Emmanuel Peters, Emmanuel Onyebuchi Ezendiokwere, Uche Chinedu Njoku1, Ikehide Friday1 and Matthew Owhonda Wegwu1 Phytochemical Composition and Analgesic Property of Ethanolic Leaf Extract of Maesobotrya barteri.Journ. Advan. Bio. Biotech., 201713(4): 1-8.

33. Ojewole JA. Antinociceptive, anti-inflammatory and antidiabetic effects of Bryophyllum pinnatum Crassulaceae) leaf aqueous extract. Journ. Ethnopharm., 2005,99:13-19.

34. 34. Prajna, P.S. and Rama, Bhat P. Phytochemical and mineral analysis of root of Loeseneriella arnottiana Wight. Inter. Journ. Curr. Res. Biosci. Plant Bio., 2015, 2(3): 67-72.

35. Wink, M. Phytochemical diversity of secondary metabolites. Encyclopedia of Plant and Crop Science, Taylor and Francis, Amsterdam, Germany, 2004. pp. 915-919.

36. 36. Uwemedimo E. Udo, Nyakno E. Akan and Enwongo M. Udoh. Qualitative phytochemical screening and antimicrobial activity of methanol extract of Maesobotrya barteri (Baill.) Hutch. Journ. Sci. Eng. Res. 2017, 4(9):351-355

37. Etukudo, I. Ethnobotany: Conventional and traditional uses of plant, The verdict press, Uyo, Akwa Ibom State, Nigeria, 2003, Vol 1.p 53.

38. Anoliefo, C.O. Introductory tropical plant biology. Nigeria: Uniben Press. 2006, pp. 257-362.

39. 39. Kalita, P., Mukhopadhyay, P.K., and Mukherjee, A.K. Evaluation of the nutritional quality of four unexplored aquatic weeds from northeast SIndia for the formulation of cost effective fish feeds. Food Chem., 2007103: 204-209.

40. Esenowo, G. J. Developmental Biology and plant physiology. Abeam Publishing Co. Nigeria. 2004. pp. 23168

41. 41. Indrayan, A.K., Sudeep, S., Deepak, D., Neeraj, K. and Manoj, K. Determination of nutritive value and analysis of mineral elements for some medicinally valued plants from Uttaranchal. Res. Comm., 2005, 89 (7): 1252-1255.

42. 42. Okeke, C.U. and Elekwa, I. Proximate and Preliminary Photochemical Analyses of

Avocado Pea Persea gratissima Cacrtn. F. (Family Lauracea). Nig. Journ.Bot., 2006, 9(1):159-162.

43. Kevin, A. C. Mineral Nutrients, Encyclopedia of cancer, Springer Link, 2017, p 2318-2322. 